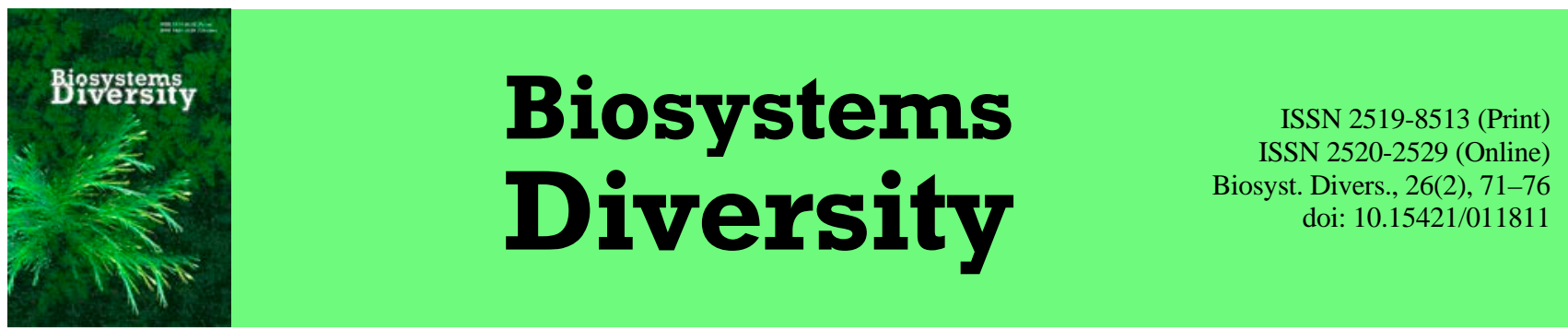

\title{
Reduction of anthropogenic loading on an agroecosystem by increasing its energy efficiency
}

\author{
T. Gnatiuk
}

\author{
Zhytomyr National Agroecological University, Zhytomyr, Ukraine
}

Article info

Received 19.02.2018

Received in revised form

07.03.2018

Accepted 09.03.2018

Zhytomyr National Agroecological University, Staryi Blvd., 7 ,

Zhytomyr, 10008, Ukraine.

Tel.: +38-093-633-25-65.

E-mail:

gnattaha2011@gmail.com
Gnatiuk, T. (2018). Reduction of anthropogenic loading on an agroecosystem by increasing its energy efficiency. Biosystems Diversity, 26(2), 71-76. doi:10.15421/011811

For full functioning, an artificially created agroecosystem should include qualitatively and quantitatively balanced components. This is possible if the anthropogenic burden on such a system is reduced and energy costs are balanced within it. In order to substantiate this statement, a production experiment was conducted in which short-term crop rotation was introduced on the land of an experimental field. Determination of energy efficiency of crop rotations and crop rotations in general was carried out by calculating technological maps of cultivating the corresponding crops. The higher the energy efficiency, the less the energy spent on cultivating crops and the less the cost of obtaining a unit of production from the corresponding area. After three years of research, we have determined that the most energy-intensive crop in short-term rotation is potatoes, less energy is spent on the cultivation of field pea-oat mixture, rye, oats with sowings of clover, and clover alone. The most energy-efficient was the organic fertilizer system (manure) for growing winter rye with a coefficient of energy efficiency of 5.10. For cultivation of field pea with oats for the same fertilizer system, the cultivation efficiency was 5.70. Growing oats with sowings of clover and using an organic system (manure) had an energy utility of 4.11. After application of the organic system (siderate) for the cultivation of winter rye, the coefficient of energy efficiency was 5.03 and for potatoes 2.21. After using the organoleptic system $50: 50$ to grow perennial grasses, this ratio was 33.05, and after the use of the mineral system for growing potatoes, 2.13. However for the cultivation of perennial grasses, we used the aftereffects of fertilizers introduced under the clover of the first year, and in the second year, under the perennial grasses, fertilizers were not applied at all, but for the cultivation of clover in crop rotation it is expedient to use an organomineral system of 50 : 50. Adhering to the basic principles of biological agriculture, namely the introduction of a scientifically grounded alternation of crops, rejecting the use of chemical plant protection products, avoiding the replacement of organic fertilizers (manure and siderate) by mineral fertilizers, it is possible to reduce energy costs for growing crops of crop rotation and crop rotation in general as a consequence, and thus to reduce the anthropogenic load on the whole agroecosystem .

Keywords: biologizing of agriculture; organic fertilizers; green manure; mineral fertilizers; productivity; energy expenditure; exit of energy

\section{Зменшення антропогенного навантаження на агроекосистему шляхом підвищення її енергетичної ефективності}

\section{Т. О. Гнатюк}

\section{Житомирський начіональний агроекологічний університет, Житомир, Украӥна}

Штучно створена агроекосистема для повноцінного функціонування має включати в себе якісно та кількісно збалансовані складові. Це можливо, якщо зменшення антропогенного навантаження на таку систему збалансувати енергетичними витратами всередині неї. Для обгрунтування цього твердження закладено виробничий дослід, в якому впроваджено короткоротаційну сівозміну на землях дослідного поля Житомирського національного агроекологічного університету. Визначення енергетичної ефективності культур сівозміни та сівозміни в цілому проведене шляхом розрахунку технологічних карт вирощування відповідних сільськогосподарських культур. Чим вищий коефіцієнт енергетичної ефективності, тим менше витрачено енергії на вирощування культур і тим менше витрати на отримання одиниці продукції $з$ відповідної площі. Після трьох років досліджень найбільш енергоємним у короткоротаційній сівозміні виявилося вирощування картоплі, менше енергії витрачено на вирощування пелюшко-вівсяної суміші, жита, вівса з підсівом конюшини та конюшини. Енергетично найвигіднішою виявилась органічна система удобрення (гній) для вирощування жита озимого з коефіцієнтом енергетичної ефективності 5,10. Для вирощування пелюшко-вівса за тієї ж системою удобрення ефективність вирощування склала 5,70. Вирощуючи овес із підсівом конюшини та застосовуючи органічну систему (гній) отримали енергетичну вигідність 4,11. Після застосування органічної системи (сидерат) для вирощування жита озимого отримали коефіцієнт енергетичної ефективності 5,03 та для картоплі 2,21. Після використання органо-мінеральної системи $50: 50$ для вирощування багаторічних трав цей коефіцієнт становив 33,05, а після застосування мінеральної системи для вирощування картоплі - 2,13. Хоча для вирощування багаторічних трав ми використали післядію добрив, унесених під конюшину першого року, а на другий рік під багаторічні трави не вносились добрива взагалі, проте для вирощування конюшини у сівозміні доцільно використовувати органо-мінеральну систему $50: 50$. Дотримуючись головних принципів біологічного землеробства (впровадження науково обгрунтованого чергування культур, відмови від хімічних засобів захисту рослин, відмови чи 
заміни мінеральних добрив органічними - гній та сидерат), можна знизити енерговитрати на вирощування культур сівозміни та сівозміни в цілому як наслідок і тим самим зменшити антропогенне навантаження на всю агроекосистему.

Ключові слова: біологізація землеробства; органічні добрива; сидерат; мінеральні добрива; урожайність; витрати енергії; вихід енергії

\section{Ветуп}

Агробіоценоз - штучно створена система рослинних і тваринних угруповань із маловираженим механізмом саморегуляції, прогнозована продуктивність яких регулюється за рахунок прямих і опосередкованих енергетичних інвестицій, після припинення або критичного зменшення яких система деградує (Smahlii et al., 2004; Blancard \& Martin, 2014). Ми спробували встановити енергетичну доцільність застосування систем удобрення з різним насиченням органічними та мінеральними добривами та 3 компенсацією поживних речовин за рахунок побічної продукції та сидератів у короткоротаційній сівозміні.

Необхідність чергування культур у просторі та часі - один із невід'ємних чинників успішного отримання високих врожаїв не тільки в інтенсивній системі землеробства, а й у біологічному землеробстві також (Klaus et al., 2013; Tittonell, 2014; Tuck et al., 2014). За умов дотримання основних принципів біологічного землеробства сівозміна - головний елемент біологізації, за допомогою якої вдається не тільки збалансувати елементи живлення сільськогосподарських культур, а й поступово відновити та підвищити родючість грунту для отримання сталих врожаїв, запобігти появі та поширенню хвороб, шкідників та підвищити конкурентоздатність вирощуваних культур для врегулювання забур'яненості посівів (Magdoff, 2007; Tuomisto et al., 2012; Carr et al., 2013).

На нашу думку, питання щодо комплексного підходу до збалансування живлення культур і отримання якісного екологічно чистого урожаю за мінімальних витрат, якнайменшого застосування хімічних засобів і дотримання принципів біологізації землеробства досліджено не в повному обсязі. Тому у нашій роботі впроваджено комплексний підхід і поєднано низку заходів, серед яких упровадження науково обгрунтованої сівозміни 3 підбором взаємодоповнювальних культур, використання органічних добрив та сидератів, які забезпечують збалансоване живлення культур, компенсація поживних речовин та їх збалансування не тільки органічними добривами, а і помірними нормами мінеральних. Наші дослідження слугуватимуть добрим доповненням у вивчення цього питання в науковій літературі.

За науково обгрунтованого чергування культур сівозміни та сприйняття ії як цілісної системи, здатної до саморегулювання, впливу на головні складові ланки (елементи) за рахунок тісного взаємозв'язку, виникає можливість регулювати наявність та кількість шкодочинних факторів, і тим самим зменшувати навантаження в агробіоценозі (de Ponti et al., 2012; van Bruggen et al., 2016). Саме такий підхід застосовують у біологічному землеробстві. Зменшення навантаження на агроекосистему шляхом мінімізіції або припинення застосування хімічних методів захисту рослин також зменшує витрати пального, економічні витрати, витрати людської праці, зношування техніки, що, у свою чергу, зменшує енерговитрати під час вирощування сільськогосподарських культyp (Pimentel et al., 1983; Strašil et al., 2015; Tinde et al., 2017).

В умовах дослідного поля Державного національного агроекологічного університету в стаціонарному досліді вперше запропоновано систему компенсації частини мінеральних добрив відповідною кількістю органічних, збалансованих за співвідношенням елементів живлення. Крім того, запропоновано заміну традиційних органічних добрив (гною) альтернативними джерелами (солома, сидерати, післяжнивні рештки) з урахуванням співвідношення елементів живлення в органічній речовині.

Для кожної агроекосистеми властивий певний енергетичний обмін, де головні джерела енергії - сонячна радіація, завдяки якій відбувається фотосинтез і антропогенна енергія.

Сільськогосподарське виробництво України все більше використовує сировину та енергію, 3 кожним роком зростають його енергетичні ресурси. 3 метою визначення найбільш енергетично доцільної системи удобрення короткоротаційної сівозміни ми провели дослідження енергетичної ефективності як окремих культур сівозміни, так і сівозміни в цілому. Встановлено енергетичну ефективність і доцільність сівозміни з різним насиченням органічними та мінеральними добривами та 3 компенсацісю поживних речовин за рахунок побічної продукції та сидератів.

\section{Матеріал і методи досліджень}

На землях дослідного поля ЖНАЕУ Черняхівського району Житомирської області предено дослід зі створення систем землеробства 3 компенсацією елементів живлення грунту, внесенням органічних добрив, рослинних решток і сидератів, щоб цим забезпечити розширене відтворення родючості грунтів і сталість землеробства в зоні Полісся. Цей дослід включав короткоротаційну сівозміну та шість варіантів систем удобрення. Сівозміна складалася 3 таких полів і культур: поле 1 - пелюшко-вівсяна суміш, 2 овес із підсівом конюшини, 3 - багаторічні трави (конюшина), 4 картопля, поле 5 - жито озиме. Варіанти систем удобрення, які застосовували у сівозміні для порівняння та вивчення: 1 - біологічний контроль, 2 - органічна система (гній, 50 т/га під картоплю), 3 - органо-мінеральна система (50\% органічних добрив і 50\% мінеральних добрив), 4 - органо-мінеральна система (75\% органічних і $25 \%$ мінеральних добрив), 5 - органічна система (сидерат), 6 - мінеральна система удобрення.

1. На ділянці біологічного контролю ми будь-яких добрив не вносили, але на полі залишали усі післяжнивні рештки, крім насіння. Таким чином зроблено спробу імітувати природне середовище 3 найменшим людським втручанням. Контрольна ділянка введена на всіх п'яти полях сівозміни (жито озиме, картопля, багаторічні трави, овес із підсівом конюшини, пелюшко-овес) та у триразовій повторності досліду.

2. Органічна система (гній) включала внесення гною в нормі 50 т/га під картоплю. Гній вносили восени після збирання попередньої культури шляхом рівномірного розкидання на всій площі ділянки і лише під картоплю, тобто раз на п'ять років, на інших культурах сівозміни досліджували його післядію. Таку ділянку розташовували на всіх полях сівозміни у триразовій повторності.

3. Органо-мінеральна система (50 : 50) включала $50 \%$ органічних добрив (гною) та 50\% мінеральних, загальний вміст внесених елементів у грунт однаковий як порівняно з органічною системою (гній), органо-мінеральною системою (75 : 25), так і з мінеральною системою. Різниця між цими системами удобрення - лише у способах внесення головних елементів живлення. Цей баланс визначали з урахуванням того, що в 1 т гною міститься $\mathrm{N}-200$ кг, $\mathrm{P}-100$ кг, К - 250 кг. Як добрива хімічного походження використовували суперфосфат (20\%), хлористий калій (51\%) і аміачну селітру (34\%). При цьому враховано вміст головних елементів живлення у побічній продукції - соломі, яка лишалася на полі та у подальшому зароблялася у грунт. Ми врахували, що після жита озимого, пелюшко-вівса та вівса солома лишалася на полі, для іiї кращого розкладання на кожну 1 т соломи використано по 10 кг азоту.

Для кожної культури системи удобрення розраховували окремо, залежно від особливостей певних культур. На органо-мінеральних системах 50 : 50 та $75: 75$ на полі з пелюшко-вівсом азотні добрива не вносили через те, що наявність однорічної бобової культури здатна забезпечити грунт азотом самостійно за рахунок симбіозу з бульбочковими бактеріями.

4. Органо-мінеральна система 75 : 25 включала внесення $75 \%$ органічних і 25\% мінеральних добрив $\left(\mathrm{N}_{12,5} \mathrm{P}_{10,0} \mathrm{~K}_{17,5}\right)$ та гній $(37,5$ т/га). Цю систему удобрення використано на всіх полях сівозміни у триразовій повторності. На полі сівозміни з багаторічними травами добрива вносили згідно з відповідними системами удобрення, але у перший рік розвитку конюшини - як під покривну культуру, а на другий рік культура розвивалась за рахунок запасу поживних елементів у грунті та післядії добрив за минулий вегетаційний сезон. 
5. Органічна система (сидерат) включала вирощування сидеральної культури після збирання основної культури. Як сидеральну культуру обрали гірчицю білу, заміняючи цим гній із коефіцієнтом перерахунку 0,8 на умовний гній у розмірі 16 т/га. Сидеральну культуру висівали під пелюшко-овес і овес із підсівом конюшини, на інших полях сівозміни спостерігали післядію сидерату.

6. Для мінеральної системи удобрення ми використовували помірні норми внесення основних елементів живлення грунту з урахуванням агротехнічної характеристики ясно-сірого лісового грунту, його вбирних властивостей і особливостей культур сівозміни. Найбільші норми внесені під картоплю, порівняно середні - під жито озиме та овес із підсівом конюшини, а найменша кількість добрив хімічного походження - під пелюшко-овес.

У короткоротаційній сівозміні протягом трьох років дослідження отримано дані відповідно до загальноприйнятих методик. По всіх культурах сівозміни складали технологічні карти вирощування культур відповідно до регіону вирощування. Енергетичну ефективність систем удобрення визначали на основі технологічних карт за методикою О. К. Медведовського та П. І. Іваненка (1988).

\section{Результати}

Найбільш енергоємні у короткоротаційній сівозміні серед усіх культур - вирощування картоплі, далі 3 меншою енергоємністю йде вирощування пелюшко-вівсяної суміші, жита, вівса 3 підсіванням конюшини та конюшини (табл. 1). У процесі вирощування картоплі найбільш енергетично вигідним виявилось застосування органічної (сидерат) і мінеральної систем удобрення. Коефіцієнт енергетичної ефективності для них - 2,0-2,4 (табл. 2). Найбільш енергозатратними та найменш енергоефективними системами удобрення стали органічна система (гній), органо-мінеральна си- стема 50 : 50, органо-мінеральна система $75: 25$, а також контрольний варіант. Коефіціснт енергетичної ефективності для цих систем коливався від 1,1 до 1,7. Органічні добрива (гній) вносили саме під картоплю, а для інших культур сівозміни у системах удобрення, де використано гній, досліджено його післядію.

\section{Таблиця 1}

Відсоткове співвідношення енергоємності вирощування культур у сівозміні (\%), середнє за 2013-2015 pp.

\begin{tabular}{lc}
\hline \multicolumn{1}{c}{ Культура } & Відсоток, $\%$ \\
\hline Конюшина & 100,0 \\
Овес із підсіванням конюшини & 191,0 \\
Пелюшко-овес & 385,2 \\
Жито озиме & 778,7 \\
Картопля & 6651,6 \\
\hline
\end{tabular}

Під час вирощування жита озимого виявлено залежність між різними системами удобрення та їх ефективністю застосування. Найвищому коефіцієнту енергетичної ефективності стабільно відповідала органічна система (гній) і органічна система (сидерат), а також у 2014 та 2015 році ще органо-мінеральна система $75: 25$. Для органічної системи (гній) коефіцієнт енергетичної ефективності у 2013 році дорівнював 3,6, у 2014 - 5,6, а у 2015 - 6,1 (табл. 3).

Для органічної системи (сидерат) у 2013 році коефіцієнт енергетичної ефективності становив 3,9, у 2014 - 5,5, а у 2015 - 5,7. Найбільші показники енергоефективності мала органо-мінеральна система 75 : 25 у 2014 році - 5,8, у 2015 - 5,3. Найменш енерговигідною системою виявилась мінеральна система, для якої у 2013 році коефіцієнт енергоефективності становив 2,3, у $2014-$ 4,7, а у 2015 - 3,9. Також найменш енерговигідною проявила себе органо-мінеральна система $50: 50$, у 2013 році коефіціснт для неї складав 2,5, у 2014 та $2015-4,4$.

\section{Таблиця 2}

Співвідношення енергетичної ефективності картоплі залежно від систем удобрення, 2013-2015 pp.

\begin{tabular}{|c|c|c|c|c|c|c|c|c|}
\hline \multirow[b]{3}{*}{ Культури сівозміни } & \multicolumn{6}{|c|}{ Роки } & \multirow{2}{*}{\multicolumn{2}{|c|}{$\begin{array}{c}\text { Середньозважені } \\
\text { показники } \\
\end{array}$}} \\
\hline & \multicolumn{2}{|c|}{2013} & \multicolumn{2}{|c|}{2014} & \multicolumn{2}{|c|}{2015} & & \\
\hline & $\begin{array}{c} \pm \text { до } \\
\text { контролю, } \\
\text { МДж }\end{array}$ & $\begin{array}{c} \pm \text { до } \\
\text { контролю, } \\
\%\end{array}$ & $\begin{array}{c} \pm \text { до } \\
\text { контролю, } \\
\text { МДж }\end{array}$ & $\begin{array}{c} \pm \text { до } \\
\text { контролю, } \\
\%\end{array}$ & $\begin{array}{c} \pm \text { до } \\
\text { контролю, } \\
\text { МДж }\end{array}$ & $\begin{array}{c} \pm \text { до } \\
\text { контролю, } \\
\%\end{array}$ & $\begin{array}{c} \pm \text { до } \\
\text { контролю, } \\
\text { МДж }\end{array}$ & $\begin{array}{c} \pm \text { до } \\
\text { контролю, } \\
\%\end{array}$ \\
\hline Контроль & - & 100,0 & - & 100,0 & - & 100,0 & - & 100,0 \\
\hline Органічна система (гній) & $-0,3$ & 77,8 & $-0,3$ & 82,4 & $-0,6$ & 70,3 & $-0,4$ & 76,9 \\
\hline Органо-мінеральна система 50 : 50 & 0,3 & 122,8 & 0,1 & 108,4 & $-0,5$ & 74,2 & 0,0 & 101,8 \\
\hline Органо-мінеральна система 75 : 25 & 0,0 & 97,6 & 0,0 & 101,2 & $-0,7$ & 68,2 & $-0,2$ & 89,0 \\
\hline Органічна система (сидерат) & 0,5 & 136,7 & 0,7 & 141,4 & 0,3 & 112,1 & 0,5 & 130,1 \\
\hline Мінеральна система & 0,6 & 141,1 & 0,6 & 137,4 & 0,0 & 100,9 & 0,4 & 126,5 \\
\hline
\end{tabular}

Таблиця 3

Співвідношення енергетичної ефективності жита озимого залежно від систем удобрення, 2013-2015 pр.

\begin{tabular}{|c|c|c|c|c|c|c|c|c|}
\hline \multirow[b]{3}{*}{ Культури сівозміни } & \multicolumn{6}{|c|}{ Роки } & \multirow{2}{*}{\multicolumn{2}{|c|}{ Середньозважені показники }} \\
\hline & \multicolumn{2}{|c|}{2013} & \multicolumn{2}{|c|}{2014} & \multicolumn{2}{|c|}{2015} & & \\
\hline & $\begin{array}{c} \pm \text { до } \\
\text { контролю, } \\
\text { МДж }\end{array}$ & $\begin{array}{c} \pm \text { до } \\
\text { контролю, } \\
\%\end{array}$ & $\begin{array}{c} \pm \text { до } \\
\text { контролю, } \\
\text { МДж }\end{array}$ & $\begin{array}{c} \pm \text { до } \\
\text { контролю, } \\
\%\end{array}$ & $\begin{array}{c} \pm \text { до } \\
\text { контролю, } \\
\text { МДж }\end{array}$ & $\begin{array}{c} \pm \text { до } \\
\text { контролю, } \\
\% \\
\end{array}$ & $\begin{array}{c} \pm \text { до } \\
\text { контролю, } \\
\text { МДж }\end{array}$ & $\begin{array}{c} \pm \text { до } \\
\text { контролю, } \\
\% \\
\end{array}$ \\
\hline Контроль & - & 100,0 & - & 100,0 & - & 100,0 & - & 100,0 \\
\hline Органічна система (гній) & 0,4 & 111,6 & 0,3 & 106,1 & 0,6 & 111,3 & 0,4 & 109,7 \\
\hline Органо-мінеральна система 50 : 50 & $-0,8$ & 76,2 & $-0,9$ & 82,9 & $-1,1$ & 80,6 & $-0,9$ & 79,9 \\
\hline Органо-мінеральна система $75: 25$ & $-0,7$ & 78,4 & 0,6 & 110,6 & $-0,2$ & 96,5 & $-0,1$ & 95,1 \\
\hline Органічна система (сидерат) & 0,6 & 119,9 & 0,2 & 104,0 & 0,2 & 104,4 & 0,4 & 109,4 \\
\hline Мінеральна система & $-0,9$ & 71,9 & $-0,5$ & 90,4 & $-1,6$ & 71,1 & $-1,0$ & 77,8 \\
\hline
\end{tabular}

Енергоефективність вирощування пелюшко-вівса значною мірою залежала не тільки від систем удобрення, за впливу яких формувався врожай, а і від вдалого співвідношення певних погодних умов (вологості) та способів унесення і шляхів засвоєння (розкладання) поживних речовин (табл. 4).

У 2013 році високий показник енергетичної ефективності виявила органічна система (сидерат) - 5,6. У 2014 році з найвищим показником коефіцієнта енергетичної ефективності вийшла органо-мінеральна система 50 : 50, він становив 7,4.

Найменш ефективним варіантом виявився контрольний за всі три роки досліджень. Невеликі показники енергетичної ефектив- ності мали у 2013 році органо-мінеральна система 50 : 50 (4,8), у 2014 - органо-мінеральна система 75 : $25(6,6)$, у 2015 - органо-мінеральна система $75: 25$ (3,7), і органічна система (сидерат) $(3,7)$.

Найвищий показник коефіцієнта енергетичної ефективності $(5,6)$ виявлено в органо-мінеральної системи 75 : 25 у 2013 році.

Коефіцієнти енергетичної ефективності під час вирощування пелюшко-вівсяної суміші за всі роки досліджень для органічної системи (гній) становили 3,7-7,6. При цьому слід зазначити, що у варіанті системи удобрення, де вносили сидерат, сидеральна культура висівалась на полях із пелюшко-вівсом і вівсом із підсіванням конюшини першого року, а для інших культур сівозміни дослід- 
жувалась його післядія. Саме тому органічна система удобрення (сидерат) на полях, де висівали сидеральну культуру, мала дещо нижчі коефіцієнти енергетичної ефективності.

Проаналізувавши отримані результати розрахунків за 20132015 роки для вирощування пелюшко-вівса, можна дійти висновків, що найкращі результати за всі роки досліджень мала органічна система (гній). У 2013 році показник ефективності на даній культурі дорівнював 5,3, у 2014 - 7,6, а у 2015 - 4,1. Отримані результати за 2013-2015 роки досліджень для вирощування вівса 3 підсіванням конюшини свідчать, що найвищі показники коефіцієнта енергетичної ефективності спостерігали після застосування органічної системи удобрення з унесенням гною $(2,9-5,1)$, а найменш енергетично ефективною виявилась мінеральна система удобрення $(1,9-3,8)$ (табл. 5).

Таблиця 4

Співвідношення енергетичної ефективності пелюшко-вівса залежно від систем удобрення, 2013-2015 рр.

\begin{tabular}{|c|c|c|c|c|c|c|c|c|}
\hline \multirow[b]{3}{*}{ Культури сівозміни } & \multicolumn{6}{|c|}{ Роки } & \multirow{2}{*}{\multicolumn{2}{|c|}{$\begin{array}{c}\text { Середньозважені } \\
\text { показники } \\
\end{array}$}} \\
\hline & \multicolumn{2}{|c|}{2013} & \multicolumn{2}{|c|}{2014} & \multicolumn{2}{|c|}{2015} & & \\
\hline & $\begin{array}{c} \pm \text { до } \\
\text { контролю, } \\
\text { МДж }\end{array}$ & $\begin{array}{c} \pm \text { до } \\
\text { контролю, } \\
\%\end{array}$ & $\begin{array}{c} \pm \text { до } \\
\text { контролю, } \\
\text { МДж }\end{array}$ & $\begin{array}{c} \pm \text { до } \\
\text { контролю, } \\
\%\end{array}$ & $\begin{array}{c} \pm \text { до } \\
\text { контролю, } \\
\text { МДж }\end{array}$ & $\begin{array}{c} \pm \text { до } \\
\text { контролю, } \\
\%\end{array}$ & $\begin{array}{c} \pm \text { до } \\
\text { контролю, } \\
\text { МДж }\end{array}$ & $\begin{array}{c} \pm \text { до } \\
\text { контролю, } \\
\%\end{array}$ \\
\hline Контроль & - & 100,0 & - & 100,0 & - & 100,0 & - & 100,0 \\
\hline Органічна система (гній) & 0,7 & 115,5 & 1,4 & 122,6 & 0,3 & 107,3 & 0,8 & 115,2 \\
\hline Органо-мінеральна система 50 : 50 & 0,2 & 104,9 & 1,2 & 118,5 & 0,1 & 101,3 & 0,5 & 108,2 \\
\hline Органо-мінеральна система 75 : 25 & 1,0 & 121,3 & 0,3 & 105,1 & $-0,1$ & 97,2 & 0,4 & 107,8 \\
\hline Органічна система (сидерат) & 1,0 & 121,8 & 0,7 & 110,6 & $-0,1$ & 97,6 & 0,5 & 110,0 \\
\hline Мінеральна система & 0,6 & 113,9 & 0,5 & 108,4 & 0,0 & 99,3 & 0,4 & 107,2 \\
\hline
\end{tabular}

Таблиця 5

Співвідношення енергетичної ефективності вівса з підсіванням конюшини залежно від систем удобрення, 2013-2015 pp.

\begin{tabular}{|c|c|c|c|c|c|c|c|c|}
\hline \multirow[b]{3}{*}{ Культури сівозміни } & \multicolumn{6}{|c|}{ Роки } & \multirow{2}{*}{\multicolumn{2}{|c|}{ Середньозважені показники }} \\
\hline & \multicolumn{2}{|c|}{2013} & \multicolumn{2}{|c|}{2014} & \multicolumn{2}{|c|}{2015} & & \\
\hline & $\begin{array}{c} \pm \text { до } \\
\text { контролю, } \\
\text { МДж }\end{array}$ & $\begin{array}{c} \pm \text { до } \\
\text { контролю, } \\
\% \\
\end{array}$ & $\begin{array}{c} \pm \text { до } \\
\text { контролю, } \\
\text { МДж }\end{array}$ & $\begin{array}{c} \pm \text { до } \\
\text { контролю, } \\
\%\end{array}$ & $\begin{array}{c} \pm \text { до } \\
\text { контролю, } \\
\text { МДж }\end{array}$ & $\begin{array}{c} \pm \text { до } \\
\text { контролю, } \\
\%\end{array}$ & $\begin{array}{c} \pm \text { до } \\
\text { контролю, } \\
\text { МДж }\end{array}$ & $\begin{array}{c} \pm \text { до } \\
\text { контролю, } \\
\%\end{array}$ \\
\hline Контроль & - & 100,0 & - & 100,0 & - & 100,0 & - & 100,0 \\
\hline Органічна система (гній) & 1,1 & 158,9 & 1,2 & 129,1 & 0,4 & 110,9 & 0,9 & 133,0 \\
\hline Органо-мінеральна система 50 : 50 & 0,5 & 127,5 & 0,2 & 105,3 & $-0,1$ & 97,3 & 0,2 & 110,0 \\
\hline Органо-мінеральна система 75 : 25 & 1,0 & 150,8 & 1,2 & 131,0 & 0,3 & 107,3 & 0,8 & 129,7 \\
\hline Органічна система (сидерат) & 0,9 & 150,4 & 0,1 & 103,7 & 0,2 & 105,8 & 0,4 & 120,0 \\
\hline Мінеральна система & 0,1 & 106,3 & $-0,6$ & 83,6 & 0,0 & 101,2 & $-0,2$ & 97,1 \\
\hline
\end{tabular}

Проаналізувавши отримані результати за 2013-2015 роки досліджень вирощування вівса з підсіванням конюшини, можна зробити висновок, що найвищі коефіцієнти енергетичної ефективності спостерігали в органічній системі із застосуванням гною та складали у 2013 році - 2,9, у 2014-5,1, а у 2015 - 4,2.

Органо-мінеральна система 75 : 25 також мала високі значення коефіцієнта енергетичної ефективності, який дорівнював у 2013 році - 2,8, у 2014 - 5,2, а у 2015 - 4,1. Саме у 2013 році одним із найбілыших коефіцієнтів енергетичної ефективності виділялась і органічна система (сидерат) із показником 2,8. Найменш енергетично ефективною стала мінеральна система: у 2013 році - 2,0, у 2014 - 3,3, а у 2015 - 3,9. Ефективність даної системи виявилась майже однаковою навіть із контрольним варіантом, де у 2013 році показник був 1,9, у 2014 - 3,9, а у 2015 - 3,8. Це пояснюється тим, що хоча за мінеральної системи удобрення вносили добрива, piвень урожайності підвищувався, але витрати на вирощування культури за даної системи значно перевищили вихід енергії та не виправдовували витрат на отримання 1 ц зерна. Саме тому застосування органічної складової у системі удобрення має великий вплив на енергетичну ефективність вирощування вівса з підсіванням конюшини. Для вирощування багаторічних трав доцільним виявилось використання органо-мінеральної системи 50 : 50 у сівозміні (табл. 6), коефіцієнт енергетичної ефективності був найвищим протягом трьох років досліджень (28,5-38,7).

\section{Таблиця 6}

Співвідношення енергетичної ефективності конюшини залежно від систем удобрення, 2013-2015 pp.

\begin{tabular}{|c|c|c|c|c|c|c|c|c|}
\hline \multirow[b]{3}{*}{ Культури сівозміни } & \multicolumn{6}{|c|}{ Роки } & \multirow{2}{*}{\multicolumn{2}{|c|}{$\begin{array}{c}\text { Середньозважені } \\
\text { показники }\end{array}$}} \\
\hline & \multicolumn{2}{|c|}{2013} & \multicolumn{2}{|c|}{2014} & \multicolumn{2}{|c|}{2015} & & \\
\hline & $\begin{array}{c} \pm \text { до } \\
\text { контролю, } \\
\text { МДж }\end{array}$ & $\begin{array}{c} \pm \text { до } \\
\text { контролю, } \\
\%\end{array}$ & $\begin{array}{c} \pm \text { до } \\
\text { контролю, } \\
\text { МДж }\end{array}$ & $\begin{array}{c} \pm \text { до } \\
\text { контролю, } \\
\%\end{array}$ & $\begin{array}{c} \pm \text { до } \\
\text { контролю, } \\
\text { МДж }\end{array}$ & $\begin{array}{c} \pm \text { до } \\
\text { контролю, } \\
\%\end{array}$ & $\begin{array}{c} \pm \text { до } \\
\text { контролю, } \\
\text { МДж }\end{array}$ & $\begin{array}{c} \pm \text { до } \\
\text { контролю, } \\
\%\end{array}$ \\
\hline Контроль & - & 100,0 & - & 100,0 & - & 100,0 & - & 100,0 \\
\hline Органічна система (гній) & 2,4 & 109,3 & 2,4 & 107,2 & 2,3 & 110,6 & 2,4 & 109,0 \\
\hline Органо-мінеральна система 50 : 50 & 6,4 & 124,9 & 6,2 & 119,0 & 6,4 & 128,8 & 6,3 & 124,2 \\
\hline Органо-мінеральна система 75 : 25 & 5,4 & 121,0 & 5,2 & 116,1 & 5,2 & 123,7 & 5,3 & 120,3 \\
\hline Органічна система (сидерат) & 1,1 & 104,3 & 1,3 & 103,9 & 1,0 & 104,7 & 1,1 & 104,3 \\
\hline Мінеральна система & 4,9 & 119,3 & 5,0 & 115,3 & 5,1 & 122,8 & 5,0 & 119,1 \\
\hline
\end{tabular}

Найбільшою ефективністю на посівах конюшини вирізнялась органо-мінеральна система 50 : 50 за 2013-2015 роки досліджень. Показник коефіцієнта енергетичної ефективності в цьому випадку дорівнював у 2013 році 31,9, з нього 3,3\% припадало на насіння конюшини, а 96,6\% на сіно. У 2014 році ефективність на органомінеральній системі $50: 50$ складала $38,7,3$ них 2,7\% припадало на насіння і 97,3\% - на сіно. У 2015 році даний показник становив 28,5, 3 них 3,2\% давало насіння, а 96,8\% - на сіно конюшини. Найменшою енергетичною ефективністю для конюшини характеризувалися контрольний варіант і органічна система із застосуван- ням сидерату. Отже, під час вирощування багаторічних трав доцільно використовувати органо-мінеральну систему $50: 50$ у сівозміні, оскільки витрати енергії на вирощування даної культури пропорційні коефіцієнту енергетичної ефективності та обернено пропорційні виходу енергії від урожаю.

Наше завдання - не тільки проаналізувати ефективність застосування тієї чи іншої системи удобрення на культурах сівозміни окремо, а і визначити, яка саме ефективність вирощування для всієї сівозміни, якщо дотримуватись певної системи удобрення. Після оцінювання ефективності вирощування культур сівозміни 
зроблено певні узагальнення. Якщо просумувати всі витрати енергії на вирощування кожної культури сівозміни, вихід енергії з урожаю, витрати енергії на 1 ц урожаю та врахувати коефіцієнти енергетичної ефективності, отримаємо загальну ефективність сівозміни для кожної системи удобрення (табл. 7).

\section{Таблиця 7}

Енергетична ефективність систем удобрення сівозміни на 1 га посівної площі за 2013-2015 pp.

\begin{tabular}{|c|c|c|c|c|}
\hline Варіанти удобрення & $\begin{array}{c}\text { Усього } \\
\text { витра- } \\
\text { чено } \\
\text { енергії, } \\
\text { МДж }\end{array}$ & $\begin{array}{c}\text { Вихід } \\
\text { енергїі, } \\
\text { МДж }\end{array}$ & $\begin{array}{c}\text { Затрати } \\
\text { на } 1 \text { ц, } \\
\text { МДж }\end{array}$ & $\begin{array}{c}\text { Коефіцієнт } \\
\text { енергетичної } \\
\text { ефективності }\end{array}$ \\
\hline \multicolumn{5}{|c|}{2013 рік } \\
\hline Контроль & 13539 & 56659 & 432,3 & 7,3 \\
\hline Органічна система (гній) & 19344 & 67931 & 376,6 & 8,2 \\
\hline Органо-мінеральна система 50 : 50 & 18712 & 76281 & 446,8 & 8,7 \\
\hline Органо-мінеральна система 75 : 25 & 19419 & 74682 & 409,9 & 8,7 \\
\hline Органічна система (сидерат) & 13977 & 68250 & 360,0 & 8,2 \\
\hline Мінеральна система & 17133 & 74393 & 472,5 & 8,4 \\
\hline \multicolumn{5}{|c|}{2014 рік } \\
\hline Контроль & 13696 & 77636 & 265,6 & 9,9 \\
\hline Органічна система (гній) & 19551 & 92487 & 232,9 & 10,9 \\
\hline Органо-мінеральна система 50 : 50 & 18884 & 99548 & 258,8 & 11,3 \\
\hline Органо-мінеральна система 75 : 25 & 19294 & 99435 & 241,3 & 11,4 \\
\hline Органічна система (сидерат) & 14147 & 88283 & 240,7 & 10,5 \\
\hline Мінеральна система & 17367 & 99366 & 270,2 & 10,9 \\
\hline \multicolumn{5}{|c|}{2015 рік } \\
\hline Контроль & 13701 & 64311 & 269,8 & 7,5 \\
\hline Органічна система (гній) & 19504 & 74023 & 259,7 & 8,1 \\
\hline Органо-мінеральна система 50 : 50 & 18817 & 76556 & 292,0 & 8,4 \\
\hline Органо-мінеральна система 75 : 25 & 19217 & 75072 & 278,6 & 8,4 \\
\hline Органічна система (сидерат) & 14112 & 69459 & 261,2 & 7,8 \\
\hline Мінеральна система & 17314 & 78267 & 291,2 & 8,2 \\
\hline
\end{tabular}

Після проведення необхідних підрахунків визначено, що, незважаючи на значну перевагу органічних систем удобрення (гній) та (сидерат) для більшості культур сівозміни, найвищу ефективність сівозміни в цілому виявлено після використання органо-мінеральних систем $75: 25$ та $50: 50$. Така тенденція спостерігається протягом усіх років досліджень. Після використання цих систем удобрення прослідковується не тільки високий коефіцієнт енергетичної ефективності, а і найвищі витрати енергії для вирощування культур у сівозміні в цілому. Вихід енергії після використання органо-мінеральних систем $50: 50$ та $75: 25$ також найвищий, але витрати на вирощування 1 ц продукції сівозміни, завдяки отриманню досить високих врожаїв із ділянок із цими системами удобрення, мають невеликі показники порівняно з іншими системами удобрення.

Згідно з нашими підрахунками, органічна система (гній) має середній коефіцієнт енергетичної ефективності сівозміни порівняно $з$ іншими системами удобрення. Але водночас спостерігали найменші витрати енергії на вирощування культур сівозміни та найменші витрати на вирощування одиниці продукції сівозміни. Вихід енергії $з$ урожаю сівозміни середній порівняно 3 іншими системами удобрення.

Також можна виділити мінеральну систему удобрення, яка за енергетичною ефективністю посідає третє місце, тоді як органічна система (сидерат) має показники енергетичної ефективності, наближені до контрольного варіанта. Отже, енергетична ефективність сівозміни в цілому виявилась найвищою після застосування органо-мінеральних систем $75: 25$ та $50: 50$, але, водночас, задіяні високі витрати енергії на вирощування культур сівозміни. Проте непогані показники енергоефективності отримані після застосування органічної системи (гній), але 3 найменшими витратами енергії на вирощування культур сівозміни.

\section{Обговорення}

В агроекосистемі, де грунт - виробничий ресурс, удосконалення структури енерговитрат можна досягти не тільки шляхом регулювання використання матеріально-технічних ресурсів, а й за допомогою раціонального використання потенціалу культурних рослин, кліматичних, мікрокліматичних, грунтових умов (Medvedovskyi \& Ivanenko, 1988; Smahlii et al., 2004). Наприклад, накопичення бобовими під час симбіотичної фіксації 100 кг азоту рівнозначне збереженню 130 кг рідкого пального (Smahlii et al., 2004; Bedoussac et al., 2015).

Odum (1986) зазначає, що близько 40\% орних земель світу інтенсивно використовуються з великими енергетичними витратами. На думку Kant (1980), основні статті споживання енергії-застосування азотних добрив (43\% загальних енерговитрат) і паливномастильних матеріалів (29\% загальних витрат). Максимальну економію енергії можна забезпечити шляхом застосування біологічного азоту замість хіміко-технічного, мінімізіції обробки грунту, біологічного розпушування шляхом правильного підбирання культур сівозміни та їх чергування, а також зменшення витрат на пестициди та заміни хімічних засобів захисту рослин на біологічні (Smahlii et al., 2004; Magdoff, 2007; Bedoussac et al., 2015).

У сучасному сільському господарстві значно зростає навантаження на агроекосистему за рахунок посиленого використання хімічних методів захисту рослин від хвороб, шкідників і бур'янів (Carr et al., 2013; van Bruggen et al., 2016). Однак за науково обгрунтованого чергування культур сівозміни та сприйняття їі як цілісної системи, здатної до саморегулювання, впливу на головні складові ланки (елементи) шляхом тісного взаємозв'язку виникає можливість регулювати наявність та інтенсивність шкодочинних факторів, тим самим зменшується навантаження в агробіоценозі (Crowder \& Jabbour, 2013; Balogun et al., 2016; Peigne et al., 2016). Саме такий підхід застосовують у біологічному землеробстві. Зменшення навантаження на агроекосистему шляхом мінімізації або припинення використання хімічних методів захисту рослин також зменшує витрати пального, економічні витрати, витрати людської праці, зношування техніки, що, у свою чергу, зменшує енерговитрати під час вирощування сільськогосподарських культур (Céline et al., 2009; Dabney et al., 2009; Keshav et al., 2014).

Отже, якщо у сільськогосподарському виробництві почнуть упроваджувати на постійній основі наш підхід щодо збалансування живлення культур за мінімальних витрат, використовуючи мінімалізіцію у застосуванні хімічних засобів і дотримуючись принципів біологізації землеробства (впровадження науково обгрунтованої сівозміни з підбором взаємодоповнювальних культур, використання органічних добрив та сидератів, які забезпечать збалансоване живлення культур, із компенсацією поживних речовин та їх збалансуванням не тільки органічними добривами, а i помірними нормами мінеральних), невдовзі стане можливим відчути такі результати як підвищення врожайності вирощуваних культур, поліпшення мікробіологічних процесів у грунті, що збілышить його родючість, отримання екологічно чистої продукції за умов енергетичної збалансованості агроекосистеми в цілому (Pelosi et al., 2009; Dahal et al., 2014).

\section{Висновки}

Найбільш енергоефективними виявились органічна система (гній) для вирощування жита озимого $(5,1)$, пелюшко-вівса $(5,7)$, вівса 3 підсівом конюшини $(4,1)$, органічна система (сидерат) - для вирощування жита озимого $(5,0)$ та картоплі $(2,2)$, органо-мінеральна система $50: 50$ - для вирощування багаторічних трав (33,0), мінеральна система удобрення - для картоплі $(2,1)$.

Під час вирощування багаторічних трав використано післядію добрив, унесених під конюшину першого року, а на другий рік під багаторічні трави добрива не вносили взагалі. Зважаючи на це, доцільно у сівозміні використовувати органо-мінеральну систему $50: 50$.

Енергетична ефективність сівозміни в цілому виявилась найвищою після застосування органо-мінеральних систем $75: 25$ та $50: 50$, але одночасно здійснені високі витрати енергії на вирощування культур сівозміни. Непогані показники енергоефективності отримані також після застосування органічної системи (гній), але 3 
найменшими витратами енергії на вирощування культур сівозміни. Отже, дотримуючись науково обгрунтованої сівозміни, відмовившись від хімічних засобів захисту рослин і компенсуючи мінеральні добрива органічними, можна отримати зниження навантаження на агроекосистему та підвищити енергетичну ефективность не тільки окремо взятої сільськогосподарської культури, а і сівозміни в цілому.

\section{References}

Balogun, R. B., Ogbu, J. U., Umeokechukwu, E. C., \& Kalejaiye-Matti, R. B. (2016). Effective micro-organisms (EM) as sustainable components in organic farming: Principles, applications and validity. Organic farming for sustainable agriculture. Sustainable Development and Biodiversity, 9, 259-291.

Bedoussac, L., Journet, E. P., Hauggaard-Nielsen, H., Naudin, C., Corre-Hellou, G., Jensen, E., Prieur, L., \& Justes, E. (2015). Ecological principles underlying the increase of productivity achieved by cereal-grain legume intercrops in organic farming. A review. Agronomy for Sustainable Development, 35(3), 911-935.

Blancard, S., \& Martin, E. (2014). Energy efficiency measurement in agriculture with imprecise energy content information. Energy Policy, 66, 198-208.

Carr, P. M., Gramig, G. G., \& Liebig, M. A. (2013). Impacts of organic zero tillage systems on crops, weeds, and soil quality. Sustainability, 5(7), 3172-3201.

Crowder, D. W., \& Jabbour, R. (2013). Relationships between biodiversity and biological control in agroecosystems: Current status and future challenges. Biological Control, 75, 8-17.

Dabney, S. M., Delgado, J. A., \& Reeves, D. W. (2009). Using winter cover crops to improve soil and water quality. Communications in Soil Science and Plant Analysis, 32, 1221-1250.

Dahal, K., Knowles, V. L., Plaxton, W. C., \& Hünera, N. P. A. (2014). Enhancement of photosynthetic performance, water use efficiency and grain yield during long-term growth under elevated $\mathrm{CO}_{2}$ in wheat and rye is growth temperature and cultivar dependent. Environmental and Experimental Botany, 106, 207-220.

de Ponti, T., Rijk, B., \& Ittersum, M. K. (2012). The crop yield between organic and conventional agriculture. Agricultural Systems, 108, 1-9.

Kant, H. (1980). Zemledelye bez pluha [Farming without Plow]. Kolos, Moscow (in Russian).

Kant, H. (1988). Byolohycheskoe rastenyevodstvo: Vozmozhnosty byolohycheskykh ahrosystem [Biological plant crop: Possibilities of biological agrosystems]. Agropromizdat, Moscow (in Russian).
Klaus, V. H., Kleinebecker, T., Prati, D., Gossner, M. M., Alt, F., Boch, S., Gockel, S., Hemp, A., Lange, M., \& Muller, J. (2013). Does organic grassland farming benefit plant and arthropod diversity at the expense of yield and soil fertility? Agriculture Ecosystems and Environment, 177, 1-9.

Magdoff, F. (2007). Ecological agriculture: Principles, practices, and constraints. Renewable Agriculture and Food Systems, 22(2), 109-117.

Medvedovskyi, O. K., \& Ivanenko, P. I. (1988). Enerhetychnyi analiz intensyvnykh tekhnolohii v silskohospodarskomu vyrobnytstvi [Energy analysis of intensive technologies in agricultural production]. Urozhai, Kyiv (in Russian).

Odum, Y. P. (1986). Ekologija [Ecology]. Vol. 1. Mir, Moscow (in Russian).

Peigne, J., Casagrande, M., Payet, V., David, C., Sans, F. X., Blanco-Moreno, J. M., Cooper, J., Gascoyne, K., Antichi, D., \& Barberi, P. (2016). How organic farmers practice conservation agriculture in Europe. Renewable Agriculture and Food Systems, 31(1), 72-85.

Pelosi, C., Bertrand, M., \& Roger-Estrade, J. (2009). Earthworm community in conventional, organic and direct seeding with living mulch cropping systems. Agronomy for Sustainable Development, 29, 287-295.

Pimentel, D., Berardi, G., \& Fast, S. (1983). Energy efficiency of farming systems: Organic and conventional agriculture. Agriculture, Ecosystems and Environment, 9(4), 359-372.

Smahlii, O. F., Malynovskyi, A. S., \& Kardashov, A. T. (2004). Enerhetychna otsinka ahroekosystem [Energy assessment of agroecosystems]. Volyn, Zhytomyr (in Ukrainian).

Strašil, Z., Vach, M., \& Smutný, V. (2015). The energy effectiveness of crops in crop rotation under different soil tillage systems. Agriculture (Pol'nohospodárstvo), 61(3), 77-87.

Tinde, L. K., Acharya, S. K., \& Sai, A. K. (2017). The energy ecology in agriculture: The concept, application and management. Advances in Plants and Agriculture Research, 6(4), 1-3.

Tittonell, P. (2014). Ecological intensification of agriculture - sustainable by nature. Current Opinion in Environmental Sustainability, 8, 53-61.

Tuck, S. L., Winqvist, C., Mota, F., Ahnstrom, J., Turnbull, L. A., \& Bengtsson, J. (2014). Land-use intensity and the effects of organic farming on biodiversity: A hierarchical meta-analysis. Journal of Applied Ecology, 51(3), 746-755.

Tuomisto, H. L., Hodge, I. D., Riordan, P., \& Macdonald, D. W. (2012). Comparing global warming potential, energy use and land use of organic, conventional and integrated winter wheat production. Annals of Applied Biology. Environmental Impacts of Contrasting Farming Systems, 161, 116-126.

van Bruggen, A. H. C., Gamliel, A., \& Finckh, M. R. (2016). Plant disease management in organic farming systems. Pest Management Science, 72(1), 30-44. 